\title{
O TEATRO DE LUIGI PIRANDELLO
}

\section{Carolina Massi Albanese}

No prefácio a Seis Personaens à procura de um Autor, Pirandello assim escreve:

(...) E preciso ficar claro que a mim nunca me satisfez representar uma figura de homem e de mulher, por mais especial e característica, pelo simples gosto de representá-la; narrar um caso particular, alegre ou triste, pelo simples prazer de o narrar; descrever uma paisagem pelo simples prazer de a descrever.

Há alguns autores (e não são poucos) que têm este prazer, e, satisfeitos, não procuram outra mais. São escritores mais propriamente históricos.

Contudo, há outros que, além deste prazer, sentem uma necessidade mais profunda, pelo que admitem apenas figuras, casos, paisagens que se embeberam, por assim dizer, num determinado sentido de vida e, a partir deste, adquirem um valor universal. São escritores de natureza mais propriamente filosófica.

Tenho a desgraça de pertencer a esies últimos.(1)

1 PIRANDELLO, Luigi. Sei Personaggi in cerea daufore. Firenze, Bemporad, 1921 p. 4 
Acusado de que suas peças são demasiado cerebrais, Pirandello não refuta essa acusação, mas acrescenta: "Eu converti o intelecto em paixão". E continua: "Uma vez que o homem desconhece seu próprio destino e, todavia, quer que se the fale dele, uma ação dramática vale mais do que todas as discussōes abstratas para focalizá-lo". (2)

Na filosofia da vida e da arte, que para o dramaturgo são uma só, o senso trágico não se encontra na existência (em termos epistemológicos), mas, sim, no existir contraposto ao ser. TiLGHER( $\left.{ }^{3}\right)$ conclui que, para Pirandello, a realidade aparece em sua raiz profundamente dramática e que a essência do drama está na luta en.re a primitiva nudez da vida e a indumentária ou as máscaras com que os homens pretendem ou devem necessariamente preiender revesti-la. A vida nua. Máscaras nuas. Os próprios títulos das obras sào altamente significativos. A filosofia implícita na arte de Pirandello gira em torno do dualismo fundamental de Vida e Forma, ou como o próprio Pirandello afirma, "Persona" e "Personaggio". Trata-se de dois momentos: o primeiro sendo a condição bruta, informe, disponivel para qualquer forma que the venha imposta ou pelo próprio homem ou pela sociedade; ó segundo momento: o do personagem ou da forma, sendo essa a condição imóvel em que o homem é obrigado a repetir os mesmos gestos, as mesmas ficções, tornando-se uma parte no jogo das partes. O homem então começa como um nada definido e converte-se numa "construção", pois constrói a si próprio de acordo com os padrões da sociedade. O homem, assim, nunca é um, mas ora um, ora outro, portanto é cem mil, isto é nenhum. $\supset$ homem é obrigado a dar-se uma aparência para pocier existir: "O existir é um banal reflexo do ser, descuplicado numa fileira de espelhos".(†) Aliás a imagem do espelho ocorre em quase todas as suas peças.

"Quando um homem vive, vive e não se vê a si próprio, bom; coloquem um espelho diante dele e façam que se veja no ato de viver. Ou ficará atônito com sua própria aparência ou desviará o: olhos para não se ve:, ou então, com nojo, cuspirá em sua imagem, ou, ainda, cerrará os punhos para quebrá-lo. Numa palavra, ocorre uma crise e essa crise é o meu testro".(5)

2 PIRANDELlo, Luigi. Teatro e letteratura. In: - - Saggi, poesia - scritti veri. Milano, Mondadori, 1960. p. 802

3 TILGHER, Adriano. II teatro di Luigi Pirandello. In: Studi sul teatro confumporaneo. Roma, Bontempelli, 1922. p. 157

4 PIRANDELLO, Luigi. Teatro e lefteratura...., p. 987

5 Ibid, p. 740 
A arte, para Pirandello, é superior à vida porque :em objetivo, significado e organização.

Resumindo:
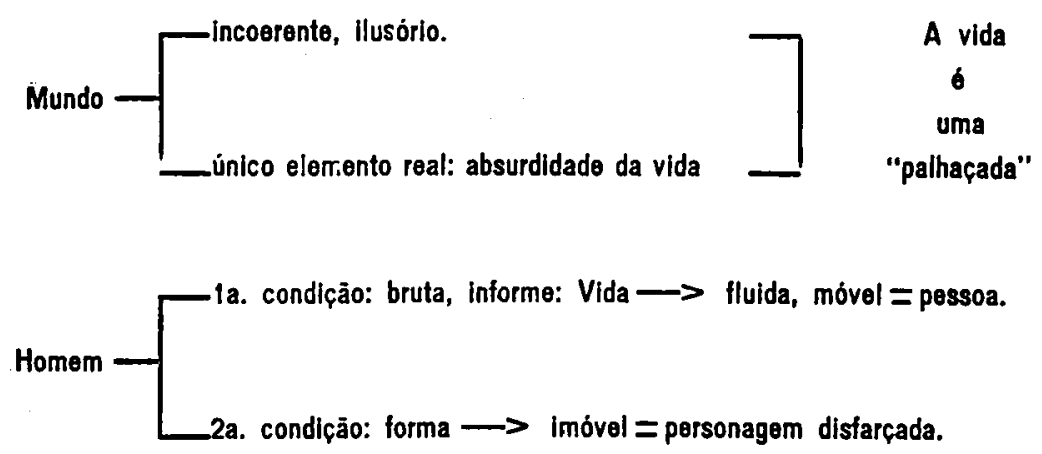

Porsonagem $\left[\begin{array}{c}\text { Uma parte } \\ \text { Uma máscara }\end{array}\right]$ Fiç̧ão = Fingimento - simulação.
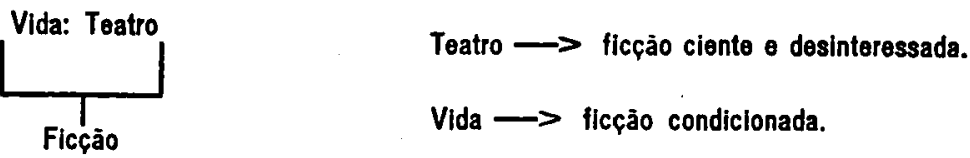

\section{Os Dramas}

Mais de quarenta são os dramas produzidos por Pirandello durante vinis e cinco anos. $\left(^{(5)}\right.$ Muitos derivam fielmente de suas novelas anteriores; outros as tomam como base, mas chegam a uma conclusão diferente; outros são novos. Se os primeiros diramas apresentam um relevan'e caráter regional, logo a insularidade do tema e do ambiente desaparece completamente. Trata-se sobretudo de um teatro de ruptura com a tradição e a convenção, que dominaram a cena italiana do dramaturgo Goldoni em diante; um teatro que se afasta do clima romântico naturalista e do limitado ambiente verístıco; um teatro que renuncia à ilusão do real. $O$ que coloca. Piran-

6 Todos os dramas de Pirandelio encontram-se recolhidos em dois volumes sob - tífulo Maschere nude (Máscaras nuas). Milano, Mandadori, 1958 (5.० ed. 1971) 
dello em lugar dessa tradição ou prática centenária teatral que ele rejeita? Coloca uma lógica frequentemente perturbadora e impieansa, que leva a afirmar que a arte é verdade, enquanto que a vida é falsa, que a ficçāo é realidade, que a personagem vive e o homem não.

A primeira fase da dramaturgia pirandelliana destaca-se graças a duas comédias em dialeto siciliano: Liola e Pensaci Giacominot escritas no espaço de poucos meses, em 1916. Estamos ainda longe do "teatro do espelho", quando os personagens viverão olhando-se viver, mas o caminho em direção a essa nova dimensão teatral estó aberto. O escritor não se satisfaz unicamente acompanhando a vida de seus primeiros protagonistas: o humorismo ensinou-the a desmontar a realidade $e$ a individuar o mecanismo por meio de uma lógica cerrada, à luz da qual há o conto, os fatos; de outro, a consciência, a reflexäo destes fatos. Isto quer dizer que o teatro se desdobra sobre si próprio para examinar-se e analisar-se, e adquíre dois modos de ser, de expressar-se.

EmPensaci Giacominol (Pense nisso Giacominol)estes dois niveis estão presentes. De um lado estão aqueles que, súcubos de um falso formalismo moral, oferecem ao autor a ocasião para uma reconstrução objetiva dos fatos; do outro lado, o professor Toti que, por sua rebe!dia à ambigüidade de normas injustas, coloca-se como individualidade subjetiva, favorece uma revisão crítica da siłuação quanto à sua interioridade.

O descompasso que surge na colisão destes dois planos abre o caminho para um novo teatro, ou melhor, para uma nova consciência do teatro que já se delineia nitidamente em Cosí è (se vi pare) (Assim é se lhe parece) (1917). O drama não é mais uma versão dos fatos concretos, encaminhados para uma conclusão, mas traduz uma situação aberta a todas as possiveis soluções, ligada àquele descompasso que surge toda vez que a sociedade se coloca contra - mundo do indivíduo e o exclui do ritmo normal das coisas. A introdução do personagem Laudisi em Cosl è (se vi pare) é o fato novo do drama, o elemento que permite uma renovaçäo interna do cróprio momento teatral. A sua presença constante, as atitudes sarcásticas que interpretam o movimento dos outros protagonisłas o diferenciam. E significa que 0 drama está em função do personagem Laudisf, ao passo que os outros personagens o são em função 
do drame.

Nesta busca de um novo teatro ocupam um lugar importante as obras escritas entre os anos 1917 e 1920, pois elas se identificam cado vez mais com uma "situação" e cada vez menos com umo "representação", enquanto que os personagens começam a perder o clichê de intérpretes de um papel, para se tornarem criadores do próprio caso.

Os protagonistas de II piacere dell'onesta, II berretro a sonagli, II givoco delle parti, Tutto per bene, para viverem precisam apoiarse num enredo exterior, não são ainda figuras autônomas. Eles se realizam numa "parte", mas é exatamente graças a essa "c"parte". aceita mediante uma participação intensa, que eles se transformam de "mimos" da realidade em criaturas autênticas e se identificam com seu papel. E que o drama e o personagem pirandellianos tornam-se assim, quando não interpretam uma situação, mas assumem-na de tal forma que se identificam com ela e adquirem a capacidade de reconstrul-la "ex novo", com respeito ao dado de partida e ao lógico desenvolvimento.

Em II piacere dell'onesta (O prazer da honestidade), a transformação de Baldovino, que no início aceitara a parte do marido defensor da honra da esposa, e mais tarde passa a ser de "objeto" do mecanismo, a criatura viva que se abandona às próprias paixões e impulsos, repropõe uma nova situação, gera um segundo caso do primeiro caso proposto pelo autor.

O mesmo se dá com Leone Gala em II gioco delle parti $(O$ jogo das partes). A esposa Silia o trai e procura fazê-lo matar. O fato não se desenrola nos termos previslveis, pois é Leone que segura as rédeas do jogo. No momento do duelo exigido pela esposa, Leone envia o seu rival, pois compete ao amante defender a honra de Silia: o amante, para Leone, é o verdadeiro marido! $O$ episódio se enriquece de uma lógica capciosa, que coloca na sombra o enredo dos acontecimentos, para ocupar-se do íntimo dos personagens, de suas relações com eles próprios e com os outros. Eles alcançaram a capacidade de se verem vivendo e de ver os outros viverem. "Contentar-se - afirma Leone - não só em viver unicamente por nós mesmos, mas em olhar os outros viverem, e também ver-nos nós mesmos vivendo, por aquele pouco que somos obrigados a viver". 
Temos um teatro no teatro. Chegamos aos Seis Personagens à procura de um Autor, e ao Henrique IV!

\section{O Deforme a o Humorismo}

Ainda que sumariamente, apesar de me:ecer um futuro estudo à parte, é útil considerar o porquê das deformidades físicas ou psíquicas das criaturas pirandellianas. Essa violência à realidade é, no fundo, uma supra realidade que desabrocha de uma Weltanshauung e de uma poética: o homem impossibilitado de se realizar numa concreia dimensão do real, o personagem deforme e infeliz por aquele "além mais" que está condenado a procurar e nāo consegue encontrar. Esse repertório do deforme é, poitanto, devido não ao fato de o autor "perceber o contrário", o que resultaria na comicidade, mas no de "sentir o contiário": um particular sentimento do mundo. Aliás, o ensaio pirandelliano L'Umorismo (1908)( $\left.{ }^{7}\right)$ pode ser considerado o prefácio cronológico e ideológico de toda a obra dramática: a concepção nele lançada se tornará o motivo central do teatro pirandelliano.

"O humorismo... leva a refletir que a vida, não sendo fatalmente, pela razão humana, um fim claro e deierminado, deve, para não andar às cegas na escuridão, ter um fim particular, fictício, ilusório, para cada homem, seja baixo ou alto".

A consciência crítica da ficção assumida como realidade é o princípio que preside à teoria crítica do humorismo e à sua presença ativa na obra pirandelliana. A sua assunção estética é tal, que o humorismo não é uma dimensão, isto é, não se realiza numa forma de escapismo e de riso, mas incorpora globalmente o personagem. O humorismo, como o entende esteticamente Pirandello, deve encontrar uma matéria resistente com a qual colidir, e essa resistência só pode ser achada no homem enquanto ele toma consciência de si, dos equívocos que o defromam, dos condicionamentos que The são imposios pela sociedade e, enfim, de toda aquela resistência externa ou equivocamente interior (pois ele pode fingir ser sua a falsa realidade imposta), que viola a sua individualidade e liberdade. O humorismo comporta assim a consciência da alienação, da deformação do eu que os outros impōem, e é também a consciência da luta que o eu a'ienado trava para se livrar dos condicionamentos. O humorista sabe que a simulação da força, da honestida-

7 PIRANDELLO, Luigi. L'Umorismo. Lanciano, Carabba, 1908. 
de, da prudência, é uma forma de adaptação, um hábil instrumento de luta. O artista não humorista tende a fixar a vida numa forma, a estátua num gesto, a paisagem numa visão, representa a idealidade essencial e imutável dos indivíduos e das coisas. O humorista, ao contrário, reflete a vida, a realidade, na sua multiplicidade possível e imprevisivel, sabe que no homem lutam, sem que uma prevaleça sobre as outras, quatro almas: a instintiva, a moral, a afetiva e a social. Portanto, o humorista deixa que os seus peisonagens se fixem numa forma, e nela acreditem ou finjam acreditar para se realizarem.

O objetivo de Pirandello é, então, refletir e exprimir o contraste entre o que parece e o que deve ser, é colher a mascarada frustação. Para Pirandello, não está em crise esta ou outra épaca, é o homem ontologicamente "decadente", quaisquer que sejam as situaçōes hisłóricas.

"Niełzsche dizia que os Gregos erguiam brancas estátuas contra o negro abismo para escondê-lo. Eu, pelo contrário, as derrubo para revelá-lo". Assim falava Pirandello nos últimos anos de sua vida a um amigo, entendendo por estátuas brancas as mesmas de sempre, aparentemente renovadas: justiça social, piedade religiosa.... ideais mistificados, álibi da hipocrisia e dos interesses terrenos.

\section{O Teatro no Teatro}

A maioria dos estudiosos do teatro pirandelliano engloba as peças Seis personagens à procura de um Autor (1921), Cada um a sua maneira (1924), Esta noite se improvisa (1930) e Henrique IV (1922), na assim chamada fórmula do "teatro no teatro". O próprio Pirandello ordena os três primerios dramas citados num "corpus", publicando-os e antepondo-lhes um perfácio. Apesar de terem sido escritos em diferentes fases da carreira, Pirandello fez deles uma trilogia em nome do expediente teatial que os une por um proposito comum. Pirandello procura forjar um teatro vivo, destruindo as ilusões do teatro realista; pretende tomar o maior espaço possível no palco, isto é, integrar a vida no teatro: o enredo se faz ação, as pessoas dissolvidas, desfeitas pela problemática, se realizam no palco como personagens. Os ałores já não fingem mais ser personagens, estão fingindo ser atores. O público é uma componente indispensável e fundamental do espetáculo, até o paradoxo de não haver diferença entre atores e espectado:es, pois a cada momento os Fapéis poderiam ser trocados. A platéia en'ão não é mais uma. presença receptiva, e sim, uma protagonista ativa, uma intervenção necessária, tanto quanto a do autor e dos protagonistas. Não é um teatro-representação, mas um teatro-ação. 
A nova dramaturgia (os Seis Personagens à procura de um Autor são o drama canônico) marca o fim da recitação "medium", traça os lineamentos da ficção ciente.

Contudo, De Castris escreve:

A assim chamada fórmula do "teatro no teatro", olhada mais profundamente, é a estrutura interna, institucional do teatro de Pirandello: a dialética de niveis representativos, na qual se consuma, sem solucionar-se, o conflito entre o personaem (sua vontade de "fazer teatro" isto é, de se realizar fora do tempo e do espaço numa forma absoluta) e a estrutura realística (a vida, a condenação existencial) que ele deve assumir como lugar e ambiente de seu protesto. Em cada drama de Pirandello há implicitamente uma tragédia, uma só e recorrente tragédia; em cada caso obje ivamente concluído, o desespero de um caso sem princípio nem fim: isto é, na múltipla comédia da "pesrona" a unitária tragédia do "personagem". $\left({ }^{9}\right)$

A dialética das duas dimensões fundamentais da representação pirandelliana, a realística e a simbólica, permite então a intrinseca espontaneidade da relação siłuação-condição, pessoa-personagem, realidade-ficção cênica.

Seis personagens à procura de um Autor. $\left({ }^{(0)}\right)$

(Sei personaggi senza autore)

Esta obra constitui o vértice mais expressivo no inteiro arco do teatro pirandelliano. O próprio prefácio é uma componente dinâmıca. No prefácio à obra, Pirandello afirma que ele esboçara seis membros de uma família como tema para uma "novela magnífica", mas, sem disposição para contar uma históiia diretamente "histórica", numa veia narrativa, decidiu abandoná-los. Os personagens pretendiam do atour $o$ ato de vida que os realizasse. Eles, portanto, pediam que o autor de suas "pessoas, casos, parxões" dizesse uma história. Mas a arte do autor não pode oferece: uma representação histórica (isto é, desinteressada) daqueles conteúdos; a arte do autor precisa de um sentido universal, e o criador, portanto, não poderá fazer com que os personagens sejam representados, pois não vê naquelas paixōes um sentido que lhes dê valor. Ainda no prefácio, Pirandello afirma que os personagens que o tentavam e que ele re-

9 CASTRIS, Arcangeio Leone de. Storie di Pirandello. Bari, Laterza, 1972. p. 142

10 A obra foi recentemente publicada pela Abril Cultural. Traduçäo publicada com a licença da Editora Civilizaçāo Brast.eira S.A. - Rio de Janeiro e de Elvira Rina Malerbi Bicci (Prefácio do Autor) 
cusava tinham-se iá separado dele, tornaram-se autônomos na luta que travaram com o Autor para viverem, pe:sonagens dramáticos, personagens que podem por eles próprios mover-se e falar, pois já se enxergam como tais. Por isso, o autor mandara-os ao palco. Declara Pirandello que entendeu dar ao drama de cada personagem uma outra função mais complexa e na qual a primeira função entrava apenas como um dado de fato. A função dada a eles é aquela situação impossível, o drama de estar à procura de um autor.

A renúncia à história dos seis personagens é a renúncia a todo - teatro burguês, que não era outra coisa senão um contínuo discurso sobre a família, considerada a principal instifuição da sociedade.

No prefácio, Pirandello afirma a superioridade da arte sobre a vida, por tratar-se de criação imutável, mas nem por isso estática e perecivel. Aliás, no próprio drama encontramos esse tema, do qual é acrescida a variante da superioridade do peisonagem, que é um, sobre as possiveis in'erpretaçōes dos atores que são muitas.

O drama apresenta também inovações técnicas. Comecemos por uma breve "Nota bene":

N.B. A comédia não tem atos e nem cenas. A representação será interrompida uma primeira vez, sem que o sipário seja fechado, quando o Diretor do teatro e o Diretor de cena se afastarão para arrumar o cenário e os Atores esvaziarão o palco; uma segunda vez, quando por erro, o maquinista abaixará o sipário.(11)

As didascálias sugerem soluções completamente novas, construção de cena com métodos e process ocinematográficos, em que há simbiose de movimento-gesto-palavra.

O drama principia com uma rápida cena improvisada entre funcionários, diretor, secreááio, atores: troca de idéias, de cumprimentos, até mesmo uns passos de dança.

Uma didascália diz: "Os espectadores, entranto na sala, enconirarão o sipário levantado e o palco sem bastidores e sem cenário, quase na escuridão e vazio, para que tenham desde o início a impressão de um espetáculo não ensaiado".(12)

As operações são feitas à vista do público, tais como a ordem de acender os refletroes, de situar o ponto, com o manuscrito da peça bem aberto na frente. Por uns minutos, o próprio público sentese ator, hábil expediente conseguido com a presença dos seis personagens na platéia, à espera de serem atendidos pelo Diretor. O

11 PIRANDELLO, Luigi. Sei Personaggi... p. 10

12 Ibid, p. 11 
Pirandello "metteur en scène" usará os refletores com a finalidade de isolar o personagem, de evidenciar também, ao nivel de visibilidade simbólica e supra-realista, o vulto, a mímica móvel ou a posição imóvel, a indumentária.

Uma outra disdacália: "Quem quiser fazer uma tradução cênica desta comédia deve usar todo recurso par conseguir que estes seis personagens não sejam confundidos com os Atores da Companhia".(13) E continua dando algumas sugestōes.

Desta forma, Pirandello faz questão de diferenciar também materialmente os Personagens dos Atores. O meio mais eficaz e idôneo por ele sugerido é o uso de máscaras especiais, que deixem livres os olhos, as narinas e a boca: "Os personagens de fato não deverão parecer fantasmas, mas realidades criadas, construções imutáveis da fóntasia: e, portanto, mais reais e comsistentes do que a volúvel naturalidade dos atores".(14)

Esse enredo visivo-verbal apresenta-se portanto tridimensionalmente: a história dos Personagens/a história do triunfo da arte sobre a vida/a história antagônica personagem-ator.

Os seis personagens assumem responsavelmente a consciência crítica de sua problemática situação, isto é, de estarem sem Autor, hipótese de um trabalho a ser feito, personagens de um drama que deve ser composto. Os personagens têm todas as possibilidades para conduzir eles próprios o processo judiciário. Justamente porque autônomos, assumem a responsabilidade de julgarem e de se julgarem.

O personagem pirandelliano fica sem autor e perenemente à sua procura, privado de um destino autêntico e sempre forçado a contestar a obrigação de assumir um destino inautêntico.

Os nomes e os sobrenomes desaparecem: o Pai, a Mãe, a Enteada, o Filho, o Rapaz e a Criança, puras indicaçōes de relação familiar.

A história, em resumo, é a seguinte: O Pai casara com uma mulher humilde e ignorante, de quem tivera um Filho. Ao perceber que seu secretário estava apaixonado por ela, 0 Pai mandou ambos embora e apoderou-se do Filho. A Mãe teve do amante três filhos: a Enteada, o Rapaz, a Criança. $O$ amante morre e a Mãe desamparada e pobre consegue enconträr trabalho como costureira na loja de roupas de Madame Pace. Esta, na realidade, é a Madame de um bordel, que oferece o trabalho por estar interessada na Entea-

13 lbid, p. 19

14 Ibid, p. 20 
da. De fato, ela consegue aliciar a jovem. O Pai vai ao bordel, mas a cena de amor com a Enteada (ambos desconheciam os laços de sangue) é interrompida peio grito da Mãe. A históiia é reconstruída da narrativa do Pai e das emendas da Enteada. Trala-se de uma família burguesa, de uma história bu:guesa, com todas suas típicas caractersticas: o patriarcalismo,i o moralismo convencional... A renúncia do Autor à história dos personagens é a renúncia ao teatro burguês, pois o Autor não renuncia, não recusa os peisonagens, n:as seu drama, "que era sem dúvida, de seu intesse, porém não o meu". Os fatos concretos e as ocasiões contingentes não interessam эo Autor: interessa a condição geral do homem, esboçada na temática apresentada e sofrida pelos personagens enquanto protagonistas de uma nova realidade, a das cenas. A condição dos seis personagens é a mesma do homem em busca do seu ponto de partida e de chegada. Eis por que não podemos considerar fortuitos:

1. O palco desprovido de petrechos, despido.

2. O fato de que, quando os seis personagens entram no teatro, uma companhia de atores está pretendendo representar justamente a peça pirandelliana. $O$ jogo das partes (II giuco de!le parti)

3. O fato de que os atores não conseguem representar sequer um trecho da comédia (à ordem do Diretor "Atenção! Atençãol" entram imediatamente em cena os seis peisonagens).

4. A divisão da peça em duas partes, separadas aparentemente ao acaso, como sugere a didascália (a. recusa da divisão em atos do teatro burguês).

4. O erro do maquinista ao fechar o sipário, enquanto está sendo representada a cena passional entre o Paí e a Enteada. (Ao calar-se erroneamente o sipário, ficando do lado de fora o Pai e o Diretor; o erro do maquinista desvenda a mistificação do final romântico do drama).

Podemos, então, concluir que há um p:ocesso radial de destruição das estruturas dramatúrgicas do teatro burguês. Apesar da frase do Diretor: "Precisamos representar a cena", a cena só consegue ser realizada parcialmente e o próprio final do drama é mí. mico: a criança morre afogada, o rapaz suicida-se com um tiro de pistola, a Enteada foge, os outros três personagens abandonam o palco. Há exatamente a representação da história rejeiłada.

O autor completou apenas duas cenas do drama, uma na loja de roupas de Madame Pace; a outra, no jaidim do Pai; estas duas 
cenas descrevem a pré-história do personagem, isto é, a decomposição da "persona". Na primeira parte da peça, é apresentada quase que toda a trama do drama a ser composto, como já vimos, unicamente da narrativa do Pai e das emendas da Enteada (outra desmistificação!). Na segunda parłe, há a tentativa de dramatizar essa irama que o público conhece.

O PAl - O autor que nos criou vivos, depois não pode materialmente nos colocar no mundo da arte. E foi um verdadeiro crime, senhor, pois quem tem a sorte de nascer personagem vivo, pode rir-se também da morte. Não morre mais! Morrerá o homem, o escritor, instrumento da criação; a criatura não morre mais...

O DIRETOR - Tudo isso está certo! Afinal o que querem de nós?

O PAI - Queremos viver, senhor.

O DIRETOR - (irônico) - Pela eternidade?

O PAl - Não, senhor; ao menos por um momento, nos senhores! $\left({ }^{15}\right)$

O anseio dos personagens é um anseio de ser, de encontra: !ibertação naque!e absoluto que somente a forma artística pode thes oferecer. Contudo, para viver, isto é, escapar à solidão de sua condição de personagem sem auto:, ele deve aceitar a humorística rea. lidade de uma dimensão aparente, deve resignar-se a se fazer representar, a ser reduzido à dimensão vital dos homens. O diálogo acima reproduzido é a réplica das instâncias doloridas do personagem e há a dialética (que de resto é própria de todo o drama) deformidade-anseio de forma. A angústia do personagem está em ter que trair a sua altísima tragédia de personagem. A resposta do Pai ao Direicr que the pergunta se eles querem viver pela elernidade:

"Não, senhor, as menos for um momento, nos senhores!" en. cerra a mais dilacerante ilusão-delusāo-frustação: a disparidade entre a realidade dos seis e 0 artificialismo dos intérpretes. $E$, mais adiante, o Pai dirá que, para os atores que brincam des er pessoas sérias, a interpretação é um jogo; para eles, ao contrário, seu drama é sua vida. Aliás, à soliccitaço do Pai para que os próprios personagens representem seu drama, há a resposta resoluta do Diretor de cena: "Aqui o senhor, como o senhor é, não é possível. Aqui está - Ator para representá-!o!", isto é: o personagem "autêntico" é um

15 lbid, p. 23 
intruso entre os homens burgueses.

Como o crítico LUGNANI( $\left.{ }^{10}\right)$ sutilmente observa, o mágico comrecimento de Madame Pace à cena, máscara grotesca, caricatu ral, tem por um momento a capacidade de provocar uma, reversāo de perspectivas, consegue por um minuto fazer pensar que o "perso. nagem" e o seu drama possam impor-se aos atores símbolos. De fato, há o diálogo em voz baixa entre Madame Pace e a Enteada que correra imediatamente ao seu encontro, e as exclamações de surpresa dos Aatores que se refugiam todas na pla:éia. Há depois a presença da Mãe e o diálogo penoso entre o Pai e a Enteada. Nesse ínterim, somente os Personagens estão no palco: dá-se portanto uma reversão na hierarquia de valores, que fatalmente retoma a posição inicial com a parodística prova oficial dos Atores, sublinhada e mistificada pela voz do ponto, símbolo de uma predisposição à simulação, de uma evidente dimensão fictícia.

Traduzido em termos estéticos - escreve DE BENEDETTI(17) há o conflito entre a fantasia, que desejaria suas criaturas no seu originário clima viłal, e a imaginação ávida de ver e tocar essas criaturas no mundo figurado e carnal.

\section{Cada um à sua maneira (Ciascuno a suo modo)}

A concepção diamática de Seis Personagens a procura de um Autor lançara, como vimos, uma técnica de representação e uma novíssima poética teatral, que serão aplicadas no drama Cada um a sua maneira. Aqui há a proposta de levar ao palco um drama, cujo enredo é o suicídio de Giorgio Salvi por amor de Délia Moreno, que ele pegou em flagrante enquanto o traía com Michele Rocca. O acontecimento corresponde exatamente a um episódio de crônica que abalou a cidade. Entre o público estão alguns atores que simulam serem espectadores de récita. Francesco e Doro julgam de maneira oposta a Délia, que é pub!icamente acusada de ter provocado o suicídio. Enquanto discutem, os dois acabam mudando de opinião: o acusador se torna o defensor da moça, e o defensor o acusador. Délia quer agradecer ao defensor, mas acaba ficando perturbada, pois teme que a acusação contra ela possa ser justa. Os verdadeiros implicados, a condessa Moreno e o barão Nuti, presentes no teatro, reagem violentamente. O público comenta. e julga: "Quem é o responsável moral pelo suicídio?". Surge um debate entre os personagens no palco; debatem-se também os espectadores

16 LUGNANI, Lucio. Pirandello - Letternturn - teatro. Firen:e, La Nuovo Itális, 1970. p. 135 p. 321

17 DEBENEDETTI, Giacomo. Pirandello. In: Quademi Inoditi. Mi.ano, Garzantl, 1972. 
fictícios; as opiniões mudam e se acumulam numa reviravo'ta de contradiçōes. As pessoas envolvidas, furiosas, atacam o autor e os atores, o sipário é necessariamente fechado. A peça fica assim des. provida do terceiro ato.

Se em Seis Personagens à procura de um Autor o drama ainda esłá por fazer, aqui está já feito, mas não pode ser expresso na plenitude da representação por causa do conflito que explode entre os personagens da arte e os personagens da crônica. A relação entre a realidade e aparência que em Seis Personagens... era. entre personagens e atores, em Cada um à sua maneira é entre o acontecimento teatral e o público, entie os atores e os espectadores. Aliás, encontramos diferentes níveis de espectadores, pois diante de Délia e Michele, os protagonistas Doro e Francesco representam um primeiro nivel de espectadores. Um segundo nível de público dá-se nos dois inspiradores reais do drama representado: o barão e a condessa, os quais por sua vez recitam um terceiro, constituido pelos espectadores fictícios. Mas todos os espectadores citados, jor sua vez, têm um quarto nível de espectadores: 0 público verdadeiro.

O ritmo é de simulação-desmasca:amento, e o teatro, como já observamos, está aberto à platéia.

O drama da inconsistência se evidencia, isto $e_{\text {, representa-se }}$ equele sentimento de to:al naufrágio que envolve o público e todos os protagonistas: Doro e Francesco que mudam de opiniāo; Délia que procura inutilmente a unidade de seus atos incoerentes, de sua responsabilidade de traidora e vítima; os responsáveis reais do crime que se coniradizem; o público fictício a favor e contra.

Leiamos algumas intervenções de críticos, público e autor no primeiro entreato da peça.

O interlocutor - Mas que concepção? Sabe dizer-me em que consiste essa peça?

Pirandello - Ora essa! E se a. peça não quisesse consistir? Se quisesse mostrar justamente a inconsistência das opiniōes, dos sentimentos?

Terceiro crítico - Mas digamos a verdade. Desculpemme, parece lícito destruir o caráter dos personaens? Conduzir a ação, sem começo nem fim? Retomar o drama como por um acaso, de uma discussão?

Quar:o crítico - Mas a discussão é feita a respeito des- 
te drama. E o próprio drama!(18)

EmCada um à sua maneira, a representação do terceiro ato não poderá ser feita, é o que anuncia o Diretor. Diversamente do que acontece na peça Seis Personagens à procura de um Autor, aqui chega-se a uma conclusão mais radical, no sentido de que há uma recusa ciente do terceiro ato. E o fato de que o terceiro ato, indispensável, no teatro tradicional, aqui falte, significa um grau maior de conscientização da crise.

Esta noile se improvisa (Questa sera si recita a soggetto)

A nova concepção dramática lançada em Seis Personagens à procura de um Autor e ativada em Cada um à sua maneira, é aqui colocada como objeto central de representação:

O primeiro elemento da estrutura é a superioridade đa arte sobre a vida:

A vida é, na verdade, menos real do que a arte. Uma vida não é, nem nunca pode ser, uma criação absoluta. E como poderia sê-lo esta vida que é escrava de uma ilusão atrás da outra, sempre contrariada, deformada, traída pelos acontecimentos, pelos outros homens ou pela nossa própria fraqueza, esta vida que se apaga e desaparece conosco na eternidade. A arte é que é uma realidade em si, eterna, fora do tempo, livre dos acasos, dos obstácu. los, sem outro fim que ela mesma. ${ }^{10}$

Contudo, a importância do drama está piincipalmente na firme e exata resposta pirandelliana com respeito à relação autor-diretor de cena-atores. No drama, o doutor Hinkfuss, diretor do espetácislo, anuncia, satisfeito, te: eliminado completamente $o$ autor. $A$ arte dramática - sustenta Hinkfuss - é arte cênica e deve libertar-se da escravidão do texto literário. Recusa-se a forma perene da arte, pois a arte, ossim como a vida, vive em muitas e diversas formas, na forma que cada vez the é dada.

Hinkfuss apresenta o esboço de um diama que os atores representarão improvisando sob sua direção. Os atores entram e saem de seus personagens, comentando seus papéis. No final do drama, o diretor, um pequeno tirano com enorme cabeleira, acredita ser o vencedor; na verdade, os atores, empolgados com seus papéis, entram livremente, espontaneamente nos personagens. $O$ desfecho está a indicar a necessidade do ator recompor o seu personagem, recriá-lo, para

18 PIRANDELlo, Luigi. Ciascuno a suo modo. In: Meschere nude, I ob. cit. p. 181

19 PIRANDELLO, Luigi. Questa sera si recita a soggetto. In: Maschere nude, I, Ob. cit. p. 228 
que seja seu, e prenuncia a teoria de hoje: a obra não pertence mais oo seu autor a partir do momento em que é confiada a um diretor para ser representada.

\section{Henrique IV (Enrico IV).}

Esse drama foi incluido pela maioria dos críticos pirandellianos no "co:pus" da assim chamada dramaturgia do "teatro no teatro", e com murła razão. De fato, o drama, representado um ano depois de Seis Personagens à procura de um Autor, retoma a problemática teatral e desloca definitivamente sua perspectiva. Não há aqui, como na peça anterior, o descompasso autor-personagem, pois Henrique é o indivíduo que impõe ass outros o seu tea:ro, dirigindo a ação cênica, criando sua história.

Não temos mais um palco despido, mas uma vila luxuosa transformada num castelo medieval, onde vive um nobre italiano que vinte anos artes participara de una festa trajado de Henrique IV e, ao cair do cavalo, num ardil de Bercredi, seu rival em amor, ficara louco, acreditando ser o próprio imperador. Genoni, o médico, aconselha que os outros usem também o traje de época. Na verdade, somente durante doze anos Henrique esteve louco. Ao recuperar sua sanidade mental, ele prefere continuar a viver a sua farsa de Henrique IV, pois sem a inocência das ilusões que ele perdera com a mocidade e o amor no dia da cavalgada, não é possível voltar à vida:

Eu sei que a mim, criança, parecia verdadeira a lua no poço (diz Henrique aos seus áulicos).

(...) Porque, pobres de vocês se não se agarram o que parece verdadeiro hoje, o que parecerá verdadeiro amanhã, ainda que oposto ao que lhes parecia ontem. Eu jamais gostaria que vocês pensassem, como eu fiz, nessa horrível coisa que realmente enlouquece uma pessoa; que . estiverem diante de alguém, possam ter a sensação de mendigos diante de uma porta que nunca se abre para vocês; pois aquele que realmente aí penetra nunca será qualquer de vocês, mas alguém que vocês desconhecem, dentro do seu diferente e impenetrável mundo. ${ }^{20}$

O uso sagaz dos advérbios de tempo "hoje... amanhã... ontern" marca o gráfico de um movimento circula: que abrange o presente, o futuro, o passado, e sempre se repèe lábil, sem variações, sem sentido.

Incapaz de se identificar consigo mesmo, isto é, de não mais froder se iludir, Henrique decide manter sua máscara e viver sua lou-

20 PIRANDello, Luigi. Enrico IV. In: Maschere nude, I, ob. cit. p. 89 
cura. A condição de louco, quando louco não é mais, lhe dá o privilégio de gozar de uma liberdade interpretativa e inventiva que the permite sacudir a lógica das "Construções" humanas e criar outras. Fingindo confundir os que esião ao seu redor, Henrique vira o espeTho para eles e grita: "Bufões! Bufōes! Pode-se tocar neles a música que se quiser!" E já quase ao final do drama: "E vocês (aos seus álicos) estão surpreendidos por eu lhes arrancar agora. suas máscaras ridículas, como se não tivesse sido eu que os fiz mascararem-se, para satisfazer este meu gosto de brincar de louco!"

Ele que não tem forma, constrói para si uma fo:ma para poder, viver, a. da loucura; e quando os outros the arrancam a máscara, a dolorida necessária mentira, ele se revolta e mała. De fato, chocado com um violento estrałagema suge:ido por Genoni (Frida que se parece com a mãe, a amada de vinte anos atrás, vestirá a roupa de um tempo da mãe, e, na penumbra da sala do trono, chamará o amado), Henrique se trai $\in$ ačaba confessando. Ao tentar impedir que Henrique tome frida nos braços, Balcredi é transpassado com a espada pelo próprio Henrique. $O$ homicidio representa bem mais que uma tardia vingança de amor traído, é o ato desesperado de quem vê que the tiraram a máscara e obrigado a trocar a sua altíssima tragédia de personagem com a ridícu'a comédia da vida.

Henrique IV - (...) Vou arrancar este meu traje de mascaradol E depois irei contigo. Não é mesmo?

Belcredi - Comigol Conosco!

Henrique IV - Aonde? Ao Cí:culo? De sobrecasaca e gravata branca? ${ }^{21}$

O drama se encerra com o reingresso de Henrique em seu papel de louco: um ato de rebeldia social e existencial.

\section{Da crise do personagem ao mito}

A última produção teatral de Pirandello é a p:odução das três Uiopias: a utopia social em A nova colênia (La nuova coloniia); a utopia religiosa em Lazzaro; a viopia estética em Os gigantes da Montanha, (l giganti della montagna).

Pirandello, principalmente, na última obra ciłada, tenta uma arfe fora da realidade, em que a fantasia possa criar e se identificar com os movimentos interiores da alma num território indefinível e incontrolável pela lógica. O mito, como força de arte irracional com sentido nela. própria, não mais ligada a um compromisso com a realidade.

21 PIRANDello, Luigi. Enrico IV. ... Ibid, p. 118 
O drama Os gigantes da montanha é uma obra incompleta, que c filho de Pirandello, Estêvão, procurou ultimar, baseando-se nas indicações do pai recolhidas até seus últimos minutos de vida.

Numa vila, solitária da Scalogna, num vale deserto, moram o mago Cotrone e os seus Scalognati: uma pequena comunidade de poetus que vivem de fantasia e de poesia. Um dia, chegam à vila llse uma atriz, o marido e uns companheiros, superstites de uma companhia teatral. Ilse quer representar A fábula do filho mudado, que um poeta enamorado lhe dedicou antes de se suicidar, porque não era correspondido. Cotrone convida llse a permanecer em sua casa, que é o reino da poesia, onde os sonhos da arte se realizam. Ilse recusa, pois entende representar o drama entre os homens. Ela e seus companheiros sobem a montanha, para poder apresentar a peça ao público dos Gigantes e de seus servos, homens de forte porte físico que praticam unicamente o exercício da força.

Nessa altura se encerra o drama escrito pelo autor. O epilogo é reconstruído por Estêvão: o drama não consegue ser representado, os servos matam llse $e$ os dois atores que acorreram para defendê-la. $O$ marido de llse grita que os servos mataram a poesia. Nāo, reclama Cotrone, os servos da vida mataram os servos da arte, pois a poesia é eterna.

A figura de llse é a que mais gera a tensão dramática, o ritmo evasão-empenho que surge da hesitação da atriz entre o convite tentador de Cotrone à fuga para o mundo fantástico e a vontade de levar ao palco a obra do autor suicida.

Ilse é sem dúvida o personagem mais segnificativo; sua vontade trágica se sobressai ao lirismo de Cotrone. Cotrone é o único persoragem, digarios assim, completo, pois conseguiu realizar em poesia sua própria vida e está portanto livre dos liames da vida; Ilse, pelo contrário, vinculada à sua dívida. humana (o de representar a Fábula), não consegue atingir a dimensão onírica e surrealista.

Cotrone convida llse a ficar, pois a fábula pode viver só no mundo mágico dos Scalognati, que são os únicos a compreendê-la e aceitá-la. llse responde que a poesia. para viver deve ter um público, para realizar-se deve travar um diálogo com a platéia:

Cotrone - Compreendo que a Condessa não pode renunciar à sua missão.

Ilse - Até o último instante!

Cotrone - Não quer nem mesmo que a obra viva por si mesma, como poderia somente aqui.

Ilse - Ela vive dentro de mim; mas não é o suficientel 
Deve viver no meio dos homens!

O final do drama é iluminado pela contradição insolúvel entre os servos fanáticos da arte e os servos fanáticos da vida. Assim explica Cotrone:

Não, não é que a poesia tenha sido rejeitada; mas exatamente isto: que os pobres servos fanáticos da vida, nos quais hoje o espírito não fala, embora possa falar um dia, despedaçaram inocentemente, como fantoches rebeldes, os servos fanáticos da. Arte, que não sabem falar aos homens porque se afastaram da vida, mas não com o único propósito de satisfazer-se com os próprios sonhos, mas pretendendo impô-los aos outros

O estudioso SCIACCA entrevê no diama Os Gigantes da montanha um certo senso de cristianismo nas palavras de Cotrone:

Estamos aqui à borda da vida, Condessa. As margens a um nosso mando somem; entra o invisivel: evaporam-se os fantasmas. E algo natural. Acontece o que costuma acontecer também quando estou acordado. Os sonhos, a música, a reza, o amor... todo o infinito que está nos homens, a senhora encontrará dentro e ao redor desta vila.

Isto quer dizer que é preciso libertar-se do peso do corpo, da vida dos sentidos, do raciocínio e da vontade, para dar sentido e valor à vida. No "entra o invisível", o estudioso Sciacca evidencia que não é aquele que ordena que entra no invisível, mas é o lnvisivel que desce nele, e nesse antigigantismo, na posição ascensãoespera, entrevê um sentido cristão nos limites em que, para o Crist:anismo, não é o homem que pode chegar a Deus, mas é Deus que desce nele como graça.

De outra opiniāo é DE CASTRIS, que considera Os gigantes dai montanha a ideal conclusão da hisłória de Pirandello:

"No desmoronamento de sua cândida ilusão de um consolo surrealista, de uma inversão mística da tragédia do homem, está a marca autêntica de seu destino le poeta. Quem na, última produção pirandelliana viu uma ancoragem positiva e otimística e exaltou moralisticamente esta arte, esquecendo a verdadeira e maior arte de Pirandello, não captou felizmente o provisório daquela tentativa; e quem definitivamente condenou o surrealismo pirandelliano, achando que naquela fuga se desvanecia o verdadeiro timbre dramático, não percebeu que longe de se liber:ar, 
- poeta infalivelmente retornava àquele impossivel sacrifício da tristeza e da solidária, compaixāo.

Precisamos reconhecer que nos três "mitos", como ele próprio os chamou, Pirandello esforçou-se para criar uma coletividade construtiva, mas a tentativa falhou devido ao artificialismo do discurso. Há muito lirismo, não resta dúvida, contudo os dramas, a nosso ver, estão prontos mais para a leitura do que para, a representação.

\section{REFERENCIAS BIBLIOGRAFICAS}

CASTRIS, Arcangelo Leone de. Storie di Pirandello. Bari, Laterza, 1972. 230 p. CUCCHETTI, G.

DEBENEDETTI, Giacomo. Quadomi Inodiri. Milano, Gaszauti, 1972. 8751 p. LUGNASI, Lucio. Pirandello - Lotteratura - featro. Firenze, La Nuova ltaiia, 1970. 243 p. SCIASCIA, Leonardo. L'estatismo, Kierkegaord, Pirandello.

TlLGHER, Adriano. Studi sul testro contemporaneo. Rome, Bontempelli, 1922. 469 p.

\section{RIASSUNTO}

Si tratta di un teatro di rottura con la tradizione ed il convenzionalismo che do minarono la scena iraliana dal drammatuigo Goldoni in poi. La drammaturgis piranaelliana marca la fine de.la recita "medium" e traccia $i$ ineamenti della rappresentazione sciente che fo onche tesoro di espressive innovazioni tecniche. E un teatro vivo in cui gl attori non fingono di essere personaggi, bensi di essere attori. La platea 6 protigonista attiva a tal punto da non esserc differenza tra attori e spettatori ad ogni momento le parti potrebbero essero invertite.

L'arte per Pirandello é superior alla vito perché ha fine, significato e organizzozione. L'arte é vera mentre la vita é falsa: il personaggio vive, l'uomo no. Per Pirandello non $\dot{e}$ in crisi questa o quel'a epoca, é luomo ontologicamente "decadente".

La filosofia della vita e quella defiarte sono una sola: il senso tragico non s'inconira nell'esistenza, ma ne:" "ssistare contrapposto all'essere. 